Kong. Res. J. 3(1) : 70-72, 2016

ISSN 2349-2694

Kongunadu Arts and Science College, Coimbatore.

\title{
STUDIES ON THE BACTERIAL CONTAMINATION OF SANGANUR CANAL FROM NANJUNDAPURAM ORIGIN TO NOYYAL END POINT, COIMBATORE DISTRICT, TAMILNADU, INDIA
}

\author{
Manish kumar, B., K. Anusiya devi, M. Lekeshmanaswamy* and C.A. Vasuki \\ PG and Research Department of Zoology, Kongunadu Arts and Science College, Coimbatore \\ *E-mail:ml_swamy64@yahoo.co.in
}

\begin{abstract}
The water quality with particular reference to bacterial analysis was carried out in the river Sanganur canal from Nanjundapuram origin to Noyyal end point, Coimbatore District from January 2014 to June 2014. The obtained results showed that running contamination of streams from agricultural areas was not extremely high, but it showed marked seasonal fluctuations. The bacterial parameters analyzed reveal that the canal is highly polluted with faecal material.
\end{abstract}

Keywords: Sanganur canal, Coliform bacterial count, E.coli count

\section{INTRODUCTION}

Water is a resource that has many uses, including recreation, transportation, and hydroelectric power, domestic, industrial, and commercial uses. Water also supports all forms of life and affects our health, lifestyle and economic well being. Although more than three quarters of the earth's surface is made up of water, only 2.8 percent of the Earth's water is available for human consumption (Iskandar, 2010). The most commonly used indicators for bacteriological contamination are the coliforms: total and fecal coliforms and fecal streptococci. E. coli is a subgroup of fecal coliform group, and its presence indicates the fecal pollution of groundwater (Viessman and Hammer, 2005). Oinam Jayalakshmi devi and Belagali (2005) conducted water quality assessment from different districts of southern Karnataka. The results of the study showed that a few samples have objectionable bacterial coliforms.

\section{MATERIALS AND METHODS}

\subsection{Study area and collection of water samples}

\subsubsection{Sanganur canal}

The present attempt was made to analyze the water quality status of Sanganur canal. It's a natural water body from Kurudi malai hills (Nanjundapuram origin) to Noyal river situated at a distance of just $45 \mathrm{~km}$ from the Coimbatore city.

\subsubsection{Sample collection}

For the present study, the samples were collected water Sanganur canal at below mentioned three stations.
Station I: Nanjudapuram in kurudimalai hills sample as Sample I, the origin of Sanganur canal

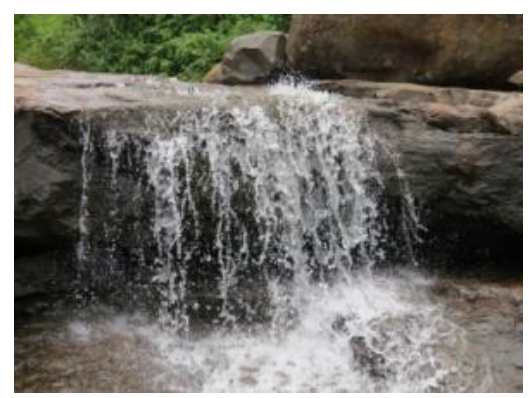

Station II: Rathinapuri water sample as Sample II of Sanganur canal.

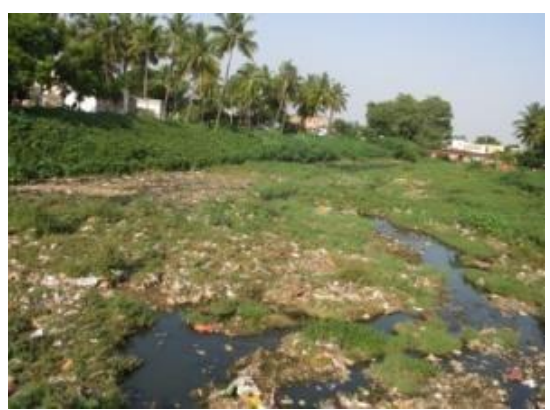

Station III : Noyyal river end point of Sanganur canal water sample as Sample III.

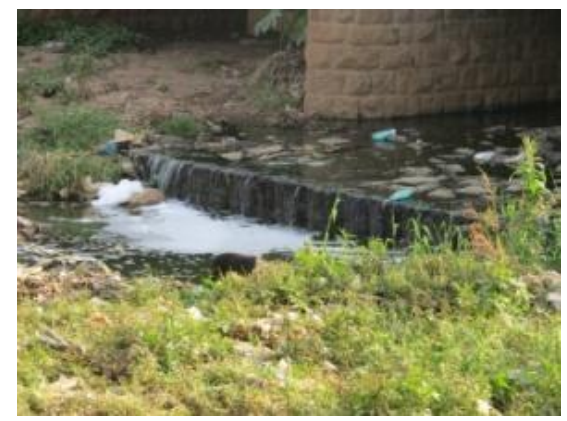


Surface water samples were collected between $11.30 \mathrm{am}$ and $12.30 \mathrm{pm}$ for a period of 6 months from January 2014 to June 2014 every fortnight. Samples were collected in a $300 \mathrm{ml}$ Borosil bottles with ample air space were transported in an ice basket and all analysis were carried out within $2 \mathrm{hr}$ of collection. All procedures were according to methods outlined and following the guideline of Anon (1976) and the American Public Health Association (APHA 1981). The most probable number of coliform bacterial count and E.coli counts (MPN/100ML) were read from the table (APHA 1981).

\section{RESULTS AND DISCUSSION}

\subsection{Standard plate counts}

The analysis of the samples for standard plate count during the study period. The populations of bacterial colonies were gradually increased during the study period at all stations. The maximum of 3.5 $\mathrm{x} 10^{3} / \mathrm{ml}$ was recorded during the first fortnight collection of June 2014 in station III and minimum of $0.8 \times 10^{3} / \mathrm{ml}$ during the first fortnight collection of June 2014 in Station I. The counts of bacterial population increased with the onset of rains and can be attributed to subsoil movement of water carrying pollutants from the catchment area into the river.

\subsection{Coliform bacterial counts (MPN)}

Variation in coliform bacterial counts (410 $750 / 100 \mathrm{ml}$ ) of the river water observed in the present study. Mean values in coliform bacterial counts for station III was higher $(750 / 100 \mathrm{ml})$ than those of the other two. The coliform bacterial counts in the residential areas were relatively very high, indicating that their occurrence for the most part was influenced by the residential activities. The minimum coliform bacterial counts were observed during January 2014. This reduction may be due to dilution and death of coliform due to their retention in the river (Holden 1970; Johari et al 1999).

\subsection{E.coli counts (MPN)}

Counts of Escherichia coli varied widely from $30 / 100 \mathrm{ml}$ to $36 / 100 \mathrm{ml}$ at Station I, $26 / 100 \mathrm{ml}$ to $30 / 100 \mathrm{ml}$ at Station II, $37 / 100 \mathrm{ml}$ to $48 / 100 \mathrm{ml}$ at Station III. E.coli can be used as bio-indicators of aquatic ecosystem dynamics and determination of their occurrence may help to assess the water quality.
Table 1. Standard plate count population in the surface water at different stations

\begin{tabular}{lllllll}
\hline SAMPLE & JAN & FEB & MAR & APR & MAY & JUN \\
\hline SAMPLE I & 0.7 & 0.9 & 0.5 & 0.8 & 0.7 & 1.0 \\
SAMPLE II & 2.9 & 2.8 & 3.1 & 2.9 & 3.1 & 3.5 \\
SAMPLE III & 1.7 & 2.0 & 1.8 & 2.0 & 2.2 & 2.1
\end{tabular}

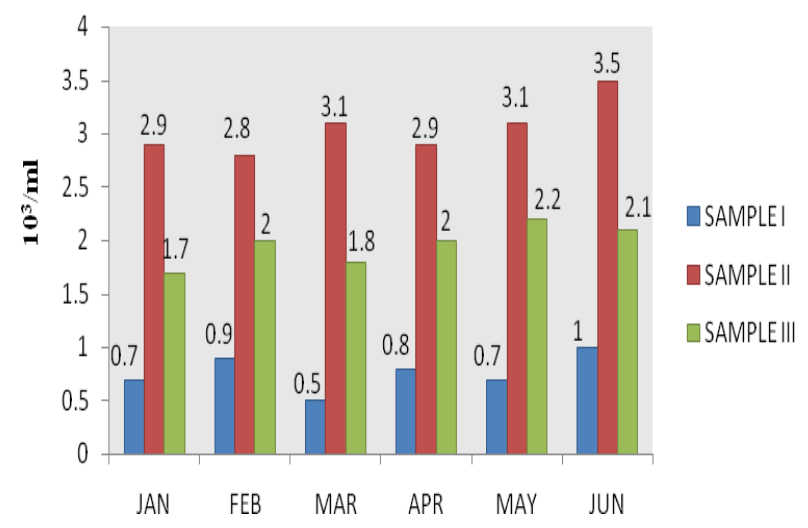

Fig. 1. Standard plate count population in the surface water at different stations

Table 2. Coliform bacterial population in the surface water at different stations

\begin{tabular}{lllllll}
\cline { 2 - 6 } SAMPLE & JAN & FEB & MAR & APR & MAY & JUN \\
\cline { 2 - 7 } SAMPLE I & 410 & 430 & 450 & 420 & 470 & 500 \\
SAMPLE II & 550 & 620 & 590 & 620 & 640 & 670 \\
SAMPLE III & 690 & 680 & 720 & 710 & 730 & 750 \\
\cline { 2 - 7 }
\end{tabular}

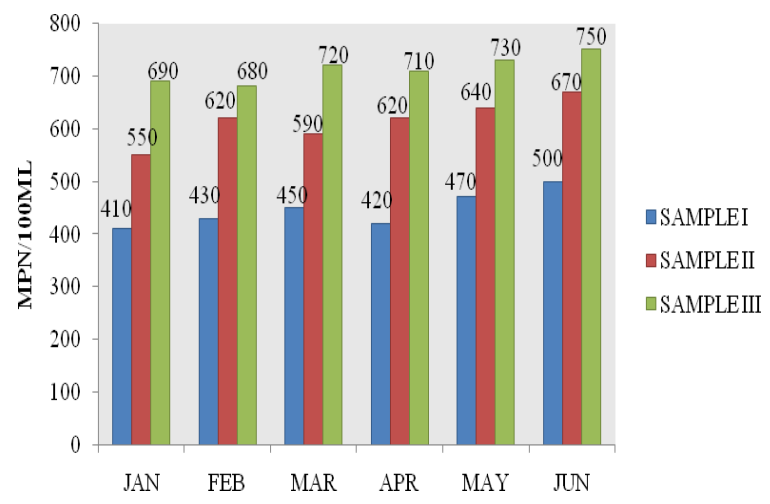

Fig. 2. Coliform bacterial population in the surface water at different stations 
Table 3. Escherichia coli population in the surface water at different stations

\begin{tabular}{lcccccc}
\hline SAMPLE & JAN & FEB & MAR & APR & MAY & JUN \\
\hline SAMPLE I & 33 & 32 & 35 & 36 & 31 & 30 \\
SAMPLE II & 26 & 29 & 30 & 28 & 27 & 25 \\
SAMPLE III & 37 & 40 & 41 & 42 & 45 & 48 \\
\hline
\end{tabular}

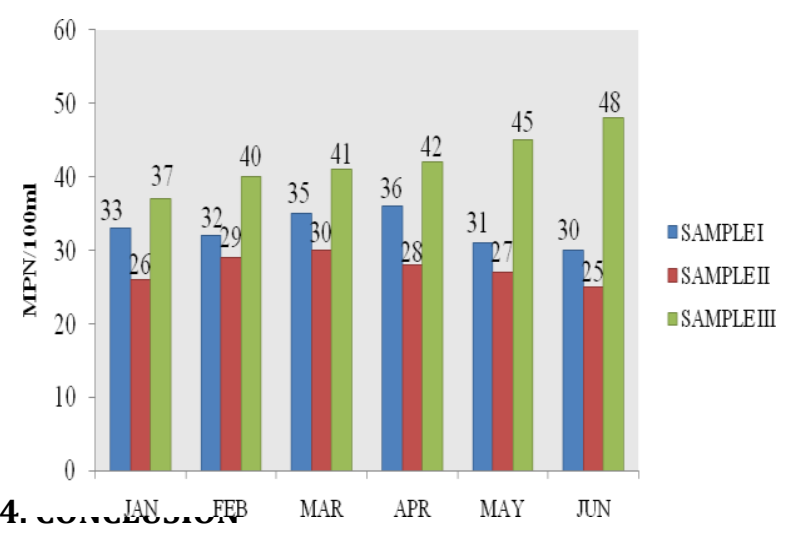

Fig. 3. Escherichia coli population in the surface water at different stations

In the present study, it has been found that the Sanganur canal waters were polluted by human and animal wastes. Therefore conservation of this canal are important to protect them from further contamination and for the human needs. This is historic earth water source for Coimbatore city. This is our duty of every individual of Coimbatore for the preservation of the canal.

\section{REFERENCES}

Anon, (1976). Standard Methods for the Examination of Water and Waste Water. Appl. Environ. Microbiol. 32:268-270.

APHA, (1981). Standard Methods for Examination of Water and Waste Water. 15 $5^{\text {th }}$ ed. American Public Health Association Inc., Washington D.C. p.1083.

Holden, W.S. (1970). Water treatment and examination. Society for water treatment and examination, J.A.Churchill, 104 Gloucester place, London. p. 513.

Iskandar, M.B. (2010). The effectiveness of biofilter as a treatment for domestic wastewater, University Malaysia Pahang (thesis).

Johari, S., Chaudhari, U.S. and Chaudhari, P.R. (1999). Eutrophic status of some lotic and lentic water bodies in American district. J. Ecotoxicol. Environ. Monit. 9: 35-40

Oinam Jayalakshmi Devi and Belagali, S.L. (2005). Water quality Assessment from different districts of southern Karnataka. Nat. Environ. Poll. Tech. 4(4):589 - 596.

Viessman, W. and Hammer, M. (2005). Water Supply and Pollution Control. $7^{\text {th }}$ ed. Prentice Hall. 